\title{
Improving The Effectiveness of Commercial Bank Employees in Cross River State through Appropriate Remuneration
}

\author{
Pius U. Angioha*, Rose U. Agba, Beauty U. Kenneth, Eno U. Ishie \\ Department of Sociology, University of Calabar, Nigeria
}

\begin{abstract}
The study specifically examines the correlation between remuneration and the effectiveness of employees in commercial banks in cross river state, adopting a survey method, data was collected from 232 participants employed by five commercial banks in cross river state. The participants were selected using the proportional stratified and simple random sampling technique. A selfdeveloped questionnaire was adopted to elicit the required information for the study. Data collected was analyzed using descriptive and inferential statistics. out of the 232 distributed questionnaires, 213 was returned and used for analysis. Result revealed a correlation between remuneration and the effectiveness of employees in commercial banks in cross river state. From the analysis 21.8 per cent of the variance in the effectiveness of bank's employees is accounted for by remuneration. The study concludes that bank the management of banks need to take into cognizance the economic situation in the country and improve on the take-home package of their employees.
\end{abstract}

Keywords: Remuneration, employee effectiveness, commercial banks.

\section{Introduction}

Globally, all organizations whether public and private, whose aim is to achieve its objective know that it has to establish a balance between the contribution that their employees make and the kind of remuneration that they get. Thus, for an organization to have a competitive edge over their competitors, they must leverage human capital in the desired direction through the power of reward (Attah \& Angioha, 2019; Balogun \& Omotoye,2020). Remuneration is payment or other forms of financial compensation given to an employee for a service rendered. According to Card and Krueger (1994), remuneration refers to the rewards that employees receive in the form of wages or salaries for service rendered to an organization or an individual. a stimulating remuneration and diverse range of other employee benefits provide organizations with a capable workforce that is effective and productive. This is because an effective and productive workforce helps an organization whether public or private to achieve their desired goal.

Studies have shown the correlation between remuneration and the effectiveness of employees (Alwakali, 2018; Calvin, 2017; Adah, Angioha, Egwuonwu and Akomaye, 2020; Angioha, Nwagboso, Ironbar and Ishie, 2018; Angioha, Enukoha, Agba, and Ikhizamah,2020). Balogun and Omotayo (2020) assessed the effect of remuneration on employee's performance. using questionnaire as the instrument of data collection, data were collected from 120 employees of global communication's limited. The result from the analyzed data using both descriptive and inferential statistics revealed a correlation between the remuneration scheme and the effectiveness of employees. Alwakali (2018) using a sample of 200 employees from companies listed on the Amman stock exchange to examine the correlation between employee remuneration and employee attitude and performance. The result from the analysis revealed that remuneration influences employee altitude to work and boost their performance. Onyekwelu, Dike, and Mougbo (2020) assessed the extent to which remuneration is a tool for employee performance. Using a sample of 200

\footnotetext{
* Corresponding author.

E-mail address: angiohapius@unical.edu.ng (Pius U. Angioha)
} 
employees of the bottling companies in Nigeria Result revealed that remuneration was a significant correlation with the performance of employees. Calvin (2017) assessed the effect of remuneration on employee productivity. Data was collected from employees of two institutions in Zamfara state, Nigeria. The result of the analyzed data revealed a significant relationship between remuneration and employee performance.

The Nigerian banking sector is one of the most competitive sectors of the economy. But in recent times, the sector has been hit with various problems, which if not checked will lead to the sectors undoing. A report by Aljazeera (2019) exposed some of the problems in the Nigerian banking sector, among which is lack of performance, poor service and customer care. A lot of these problems can be attributed to the workforce of these banks. According to Iji, Angioha and Okpa (2019) the situation that bank employee's fonds themselves do not allow them to concentrate and be productive. The bank recapitalization that started in 2005 and is still ongoing has created a situation of fear, where bank employees can lose their job at any time. bank employee takes home pay is nothing to write home about, as bank management are using the unemployment situation in the country to pay workers meagre salaries. This study specifically examines the effect of remuneration on the effectiveness of employees in commercial banks in cross river state, Nigeria.

The study adopts the incentive theory, attributed to the work of Clark Hall, the theory also known as reward motivation theory rest on the fact that motivation is fueled by the prospect of some kind of reward. The theory focuses on the relationship that exists between motivation and reward. The theory states that stimulus attracts an individual towards it. An incentive is either an act or a promise that is made to ensure greater action. It comes in the form of remuneration, job promotion and other nonfinancial or financial rewards to recognize an employee's output or encourage it. The theory is grounded in the principle of conditioning a reward to stimulate an employee. Applying this theory to this work, employees are motivated to work when the expected reward is commensurate with their output.

\section{Methods}

The survey research method was adopted for this study. The survey method was adopted because it allows the researcher to observe the participants without manipulation through the distribution of survey instrument. The population of the study are employees of five purposively selected commercial banks in cross river state, Nigeria. The banks are Access Bank, Fidelity Bank, Guaranty Trust Bank, First Bank and United Bank for Africa. According to data gathered from the banks, the population of the selected banks stands at 584.232 participants were selected from the selected banks using proportional stratified and simple random technique. The 232 participants were arrived at using the Survey Monkey Sample Determinant Technique. A self-developed structured questionnaire was used to elicit data from the participants. Ethical clearance was received that gave the researcher authority to conduct his research in the bank. Data collected from the field was analyzed using descriptive statistics such as tables, graph and frequency distribution before the data was subjected to parameter statistics at 0.05 confidence level. out of the 232instrument distributed only 213 were returned and used for analysis.

\section{Result and Discussions}

\subsection{Presentation of Result}

The first objective was to analyse the extent to which remuneration affects the effectiveness of employees in commercial banks in Cross River State, Nigeria. Frequency and percentages were first used to answer this research question and reported in table 1 before the data were subjected to parametric statistics to test for statistical significance and reported in Table 1.

Table 1. Responses on remuneration and effectiveness of employees

\begin{tabular}{llllc}
\hline S/N & \multicolumn{1}{c}{ Statement } & Very correct & Correct & $\begin{array}{c}\text { Not } \\
\text { correct }\end{array}$ \\
\hline 1 & $\begin{array}{l}\text { The remuneration I am receiving is too small when } \\
\text { compared to what other people are receiving in their } \\
\text { professions. }\end{array}$ & $117(54.9)$ & $58(27.2)$ & $38(17.8)$ \\
&
\end{tabular}




\begin{tabular}{lllll}
\hline 2 & $\begin{array}{l}\text { With the remuneration I am receiving, I still find it } \\
\text { difficult to pay my children school fees. }\end{array}$ & $54(25.4)$ & $81(38.0)$ & $78(36.3)$ \\
3 & $\begin{array}{l}\text { Each time I receive my remuneration I always } \\
\text { breakdown psychologically, because all will be used to } \\
\text { settle debt. }\end{array}$ & $9(4.2)$ & $25(11.7)$ & $179(84.0)$ \\
4 & $\begin{array}{l}\text { With the remuneration I am receiving; I don't think I } \\
\text { can build my own house without borrowing from } \\
\text { cooperative. }\end{array}$ & $114(53.5)$ & $56(26.3)$ & $43(20.2)$ \\
\hline $\begin{array}{l}\text { I always finished spending all my remuneration before I } \\
\text { receive it, because of the delay in the payment. }\end{array}$ & $96(45.1)$ & $61(28.6)$ & $56(26.3)$ \\
I always buy many things on credit, because both the & $22(10.3)$ & $16(7.5)$ & $175(82.2)$ \\
salary and other benefits are too small. & & &
\end{tabular}

*Percentages are written in parenthesis

Source: Field survey, 2020

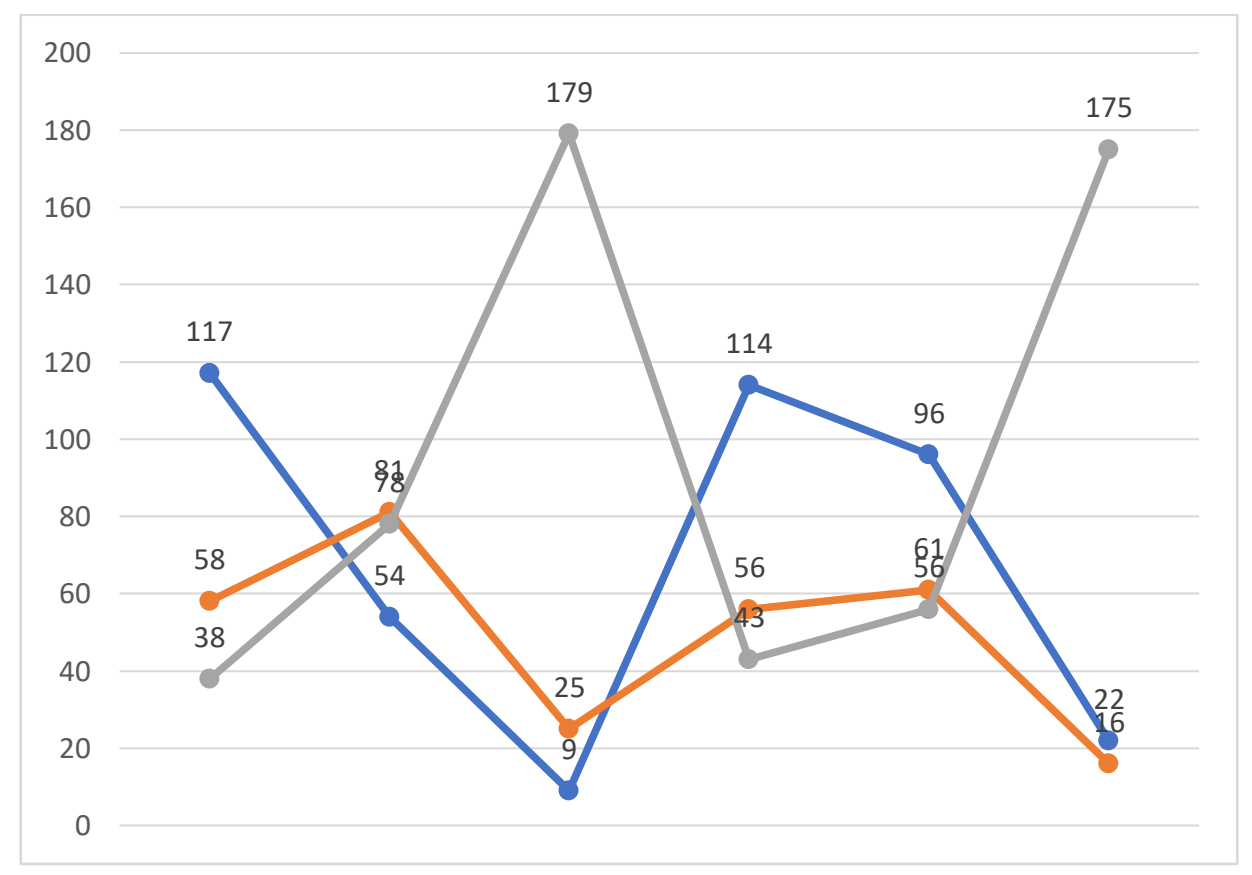

Fig. 1 Responses on remuneration and effectiveness of employees

For reporting purposes, very correct and correct were reported as agreed while not correct was reported as disagreed. As presented in Table 1, out of the 213 respondents used in this study, more than half (50 per cent) of the respondents claimed that the remuneration they received is too small when compared to what other people are receiving in their profession; 63.4 per cent agreed to item 2 "With the remuneration, I am receiving, I still find it difficult to pay my children school fees"; 79.8 per cent agreed that "With the remuneration, I am receiving; I don't think I can build my own house without borrowing from cooperative" and 79.8 per cent claimed that "I always finished spending all my remuneration before I receive it, because of the delay in the payment".

While the result was so, more than half (50 per cent) of the respondents disagreed to 2 items. Item 4 , which states that "Each time I receive my remuneration I always breakdown psychologically, because all will be used to settle debt" and item 6: "I always buy many things on credit, because both the salary and other benefits are too small". From the response of respondents to the statements in Table 1, we could conclude that remuneration is a factor that influences commercial bank employee's effectiveness in Cross River State, Nigeria. 
The data from the descriptive analysis was subjected to correlation analysis to check the statistical correlation between remuneration and the effectiveness of employees in Commercial banks. The independent variable in this analysis is remuneration while the dependent variable is the effectiveness of employees. Pearson product-moment correlation coefficient was used to test this hypothesis at 0.05 level of significance and the result is presented in Table 2

Table 2. Pearson product-moment correlation of remuneration and effectiveness of employee

\begin{tabular}{cccccc}
\hline Variable & N & Mean & SD & r-value & Sig. \\
\hline Remuneration & 213 & 12.73 & 2.12 & \multirow{2}{*}{$0.467^{* *}$} & 0.000 \\
Effectiveness of employee & 213 & 14.49 & 2.64 & & \\
\hline
\end{tabular}

*significant at 0.05 level; $\mathrm{df}=211$; critical $\mathrm{r}$ value $=0.098$.

The result in Table 2 revealed that the calculated $\mathrm{r}$-value of $0.467^{*}$ is greater than the critical $\mathrm{r}$-value of 0.098 at 0.05 level of significance with 211 degrees of freedom. The squared correlation $(0.467)^{2}$ which is a measure of effect size indicates the proportion of explained variance on the dependent variable. Therefore, 21.8 per cent of the variance in the effectiveness of employee is accounted for by remuneration. The magnitude of the effect is moderate, this means that remuneration should be considered if the effectiveness of employee is of concern. Therefore, we can conclude that there is a statistical considerable relationship between remuneration and effectiveness of employees in commercial banks in Cross River State, Nigeria.

\subsection{Discussion of Findings}

The findings of the first analysis revealed that there is statistical considerable relationship between remuneration and effectiveness of employees in commercial banks in Cross River State, Nigeria. This result implies that the kind of compensation a bank worker gets influences how effective they are in carrying out their task. The result also reveals rewards to be an 'exceptional' motivator in terms of increasing the effectiveness of employees. Increased motivation depends on what is happening then with an employee in terms of reward. Findings of the study also revealed that bank employee's remuneration is not enough to take care of their needs and family members. Findings also show that workers finish spending their salary before they are paid. This finding corroborates earlier works by Balogun and Omotayo (2020), Alwakali (2018), Onyekwelu, Dike, and Mougbo (2020) and Calvin (2017), who all found a correlation between remuneration and employee effectiveness. Balogun and Omotayo (2020) using questionnaire as the instrument of data collection found a correlation between remuneration scheme and the effectiveness of employees. Alwakali (2018) using a sample of 200 employees from companies listed on the Amman stock exchange found that remuneration influences employee altitude to work and boost their performance. Onyekwelu, Dike, and Mougbo (2020) used a sample of 200 employees of the bottling companies in Nigeria found that remuneration was a significant correlation with the performance of employees. Calvin (2017) found a significant relationship between remuneration and employee performance.

\section{Conclusions}

This study was aimed at examining the correlation between remuneration and the effectiveness of employees in commercial banks in cross river state from the analysis carried out it was discovered that a significant relationship exists between remuneration and the effectiveness of employees. Hence there is need for management of banks to have in place good remuneration that will boost the morale of their employees to make them effective management of commercial banks should formulate and implement good remuneration strategies that will enhance the attainment of the bank's objectives. 


\section{References}

Adah, J. A., Angioha, P. U., Egwuonwu, C. V. \& Akomaye, S. (2020). "An Empirical Analysis of the Relationship between Working Condition and the Effectiveness of Employees in Commercial Banks in Cross River State" Journal of Banking and Finance Management, 3(2), 2020, pp. 18-24

Aljazeera. (2019). High debt, low deposits-Nigeria's banks on the line. https://www.aljazeera.com/news/2019/01/high-debts-deposits-nigerias-banks-line-190102105104120.html

Alwaki, M. N. (2018). An Evaluation of the Impact of Remuneration on Employee Attitude and Performance in Organizations. International Journal of Academic Research in Business and Social Sciences, 8(7), 410-420.

Angioha, P. U., Nwagboso, S. N., Ironbar, A. E. \& Ishie, E. U. (2018). Underemployment: A Sociological and Policy Analysis of Workers Well-Being in Hospitality Industry in Calabar, Cross River State, Nigeria. IOSR Journal of Humanities and Social Science (IOSR-JHSS), Volume 23, Issue 6, Ver. 5 (June. 2018) PP 57-66

Angioha, P. U., Enukoha, C. U., Agba, R. U., \& Ikhizamah, G. U. (2020). Information technology predictor variables and employee productivity in commercial banks. JINAV: Journal of Information and Visualization, 1(1), 4452. https://doi.org/10.35877/454RI.jinav2125

Attah, F. M. \& Angioha, P. U. (2019); Examining the Level of Relationship Between Working Condition Predictor Variables; Remuneration, Working Hours, Office Design, Job Security and Workers Wellbeing and Productivity In Commercial Banks. International Journal of Scientific and Research Publications (IJSRP), 9(5), DOI: http://dx.doi.org/10.29322/IJSRP.9.05.2019.p896.

Balogun, A. R. \& Omotoye, O. O. (2020)."Remuneration and Employee Performance in Global Communication Limited, Lagos Nigeria." IOSR Journal of Business and Management (IOSRJBM), 22(2), pp. 15-21.

Card, D. \& Krueger, A. B. (1994): Minimum Wages and Employment: A Case Study of the Fast-Food Industry in New Jersey and Pennsylvania, The American Economic Review, 84(4), 772-793

Calvin, O. Y. (2017). The Impact of Remuneration on Employeese Performance (a Study of Abdul Gusau Polytechnic, Talata-Mafara and State College of Education Maru, Zamfara State). Arabian Journal of Business and Management Review (Nigerian Chapter), 4(2), 34-43. https://doi.org/10.12816/0037554

Iji, M. E, Angioha P. U. \& Okpa, J. T. (2019). Working Hours and Job Security: An Analysis of Their Relationship with Commercial Bank Workers Well-Being and Performance in Cross River State, Nigeria. European Journal of Economic and Financial Research, 3 (4), 1-15

Leitão, J., Pereira, D., \& Gonçalves, Â. (2019). Quality of Work Life and Organizational Performance: Workers' Feelings of Contributing, or Not, to the Organization's Productivity. International journal of environmental research and public health, 16(20), 3803. https://doi.org/10.3390/ijerph16203803

Onyekwelu, R.U., Dike, E.E, Muogbo, U. S. (2020). Remuneration as a tool for increasing Employee Performance in Nigerian. The International Journal of Social Sciences and Humanities Invention, 7(01): 5782-5789 